\title{
Tek Şehir İki Seyyah; İbrahim Hamdi ve Evliya Çelebi'ye Göre Babadağı Şehri
}

\author{
Fatma Altıok \\ (ORCID ID: 0000-0002-9683-3642) \\ Makale Gönderim Tarihi \\ 14.01.2019 \\ Makale Kabul Tarihi \\ 22.03.2019
}

\section{Özet}

Günümüzde Romanya'da bulunan Babadağı şehri 1416 yılında Çelebi Mehmed döneminde Osmanlı hâkimiyetine girmiştir. Şehir, Eflak Prensi III. Vlad Tepeş (Kazıklı Voyvoda) döneminde tahrip edilmiş; ancak daha sonra, II. Bayezid döneminde yeniden canlandırılmıştır. Şehir ismini Sarı Saltuk'tan almış olup "Babadağı" adının yanı sıra "Baba Saltuk" ismiyle de anılmıştır. Konumu itibariyle bir ordu şehir vasfına sahip olan Babadağı, 1878 Berlin anlaşmasına kadar Osmanlı hâkimiyetinde kalmıştır. Babadağı şehri, Osmanlı kültüründe önemli bir dini figür olan Sarı Saltık'ı barındırmasının yanı sıra coğrafi konumu, demografik niteliği ve kültürel vasfı itibariyle büyük bir öneme haizdi.

Şehir bulunduğu yol güzergahının işlek bir hat üzerinde olması nedeniyle sık sık ziyaret edilmiştir. Evliya Çelebi ve İbrahim Hamdi de şehri ziyaret eden ve gözlemleyen iki seyyahtır. Seksen yıllık arayla şehre gelen seyyahlarımız şehri farkı açılardan gözlemleyerek bir Babadağı resmi çizmişlerdir. Onların şehre dair anlatılarındaki farklılık Osmanlı Devleti'nin geçirdiği değişim ve dönüşümü gözler önüne sermektedir. Aradaki seksen yıllık süreç her iki seyyahın şehri algılayış ve anlatımına da yansımıştır. Bu makale iki seyyahın bir sınır şehri olan Babadağı'nı farklı zamanlarda ziyaret ederek şehre dair anlatılarını, gözlemlerini ve gözlemlerindeki benzerlik ve farkıııkları ele almaktadır.

Anahtar Kelimeler: Evliya Çelebi, Bartınlı ibrahim Hamdi Efendi, Babadağı, Sarı Saltık

* Yüksek Lisans Öğrencisi, Sakarya Üniversitesi, Sosyal Bilimler Enstitüsü, Tarih ABD, Yeniçağ Tarihi Bilim Dalı, altiokfatma@gmail.com.

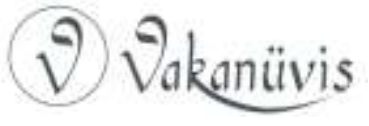




\section{Abstract}

The city of Babadağı is located in Romania today was concurred by the under Ottomans rule in 1416 during the period of Çelebi Mehmed period. This city was destroyed during the period of Vlad Tepeş (Vlad the Impaler). But it was revived period of Bayezid II. The city was namedith Baba Saltuk as well as the name of Babadağı. Babadağı, which has the status of an army city due to its location, remained under Ottoman rule until 1878 with Berlin agreement. The city of Babadağı had a great importance in terms of its location, demographic and cultural character, as well as its harboring of Sarı Saltık which is an important religious figure in Ottoman culture.

The city has been visited frequently visited due to the fact that the road route was on a busy line. Evliya Çelebi and Bartınlı Ibrahim Hamdi Efendi are two travelers who visit and observe the city. They who came to the city on an eighty year apart observed two different city from different perspective. The difference in their narratives about the city reveals the change and transformation of the Ottoman Empire. Eighty-year process is also reflected in the perception and expression of the two travelers. This article describe the similarities and differences between two travelers visiting Babadağı, a border town, at different times and observations on the city.

Keywords: Evliya Çelebi, Bartınlı Ibrahim Hamdi Efendi, Babadağı, Sarı Saltık

\section{Giriş}

Günümüzde Romanya'da bulunan Babadağı şehri 1416 yılında Çelebi Mehmed döneminde Osmanlı hâkimiyetine girmiştir. Şehir, Eflak Prensi III. Vlad Tepeş (Kazıklı Voyvoda) döneminde tahrip edilmiş; ancak daha sonra, II. Bayezid döneminde yeniden şenlendirilmiştir. Şehir ismini Sarı Saltuk'tan almış olup "Babadağı" adının yanı sıra "Baba Saltuk" ismiyle de anılmıştır. Konumu itibariyle bir ordu şehir vasfına sahip olan Babadağı, 1878 Berlin anlaşmasına kadar Osmanlı hâkimiyetinde kalmıştır. Babadağı şehri, Osmanlı kültüründe önemli bir dini figür olan Sarı Saltık'ı barındırmasının yanı sıra coğrafi konumu, demografik niteliği ve kültürel vasfı itibariyle büyük bir önemi haizdi.

Karadeniz'e yakın olması, Tuna havzasında bulunması, Tulca ile Mecidiye, Köstence yolu üzerinde, Kırım-İstanbul güzergâhında yer alması şehrin önemini daha da artırmıştır. Keza Nogay ve Tatarların




yaşadığı coğrafyanın birleşiminde kalan bir bölgede olması da şehrin hüviyetinde büyük önemi haizdir. Lehistan ve Rusya seferleri için yol üzerinde bulunması şehrin önemini arttıran faktörlerden bir diğeri idi. Özellikle Karlofça Antlaşmasından sonra şehir üs haline getirilerek yeni birlikler yerleştirilmiştir. ${ }^{1}$ Şehrin hem Karadeniz'e hem de Tuna'ya kıyısı bulunmakta idi. Silistre sancağına bağlı olan şehir Müslüman nüfusun yoğunlukta olduğu bir kent idi. Özellikle 16. ve 17.yüzyılda Kuzey Dobruca'nın merkezi haline gelmiştir. ${ }^{2}$

Osmanlıların kuzeye geçiş güzergâhının üzerinde bulunan ve stratejik olarak önemli bir noktada bulunan Babadağı şehri ve daha genelinde şehrin de dahil olduğu Kuzey Dobruca, Kırım Hanlığı'na da çok yakındı. Sayısı yüz bine ulaşan akıncılarıyla Kırım Hanlığı'nın en önemli ekonomik faaliyeti Rus, Leh ve Kazak topraklarına yönelik yağma seferleriydi. ${ }^{3}$ Babadağı havalisi ise Kırım hanlığına bağlı akıncıların yayıldıkları önemli bölgelerden biriydi. Dolayısıyla şehir, hareketli bir bölgede ve yaşamını büyük ölçüde yağma seferleriyle kazanan Tatar ve Nogayların yerleştikleri bir coğrafyadaydı. Bu yüzden Babadağı, Nogay-Tatar çekişmelerinden, Tatar-Kazak çatışmalarından ve Osmanlılarla Tatarlar arasındaki gerilimlerden doğrudan etkilenen bir şehirdi.

Osmanlı dönemi Babadağı hakkında bilgi veren çeşitli kaynaklar mevcuttur. Bunlardan biri de seyahatnamelerdir. Bu çalışma yaklaşık seksen yıl aralıkla şehri ziyaret etmiş olan iki Osmanlı seyyahı, Evliya Çelebi ve Bartınlı İbrahim Hamdi'nin Babadağı hakkındaki bilgileri değerlendirmek üzere kaleme alınmıştır. Dolayısıyla İki seyyahın şehre hangi vesilelerle geldikleri, şehirde ne kadar kaldıkları, şehirle ilgili neler anlattıkları, nasıl bir Babadağı resmi çizdikleri sorularına cevap aranmıştır.

Evliya Çelebi, kaleme aldığı seyahatnamesinde pek çok şehir hakkında bilgi vermiştir. Balkanlar'ın dışında onun Anadolu'nun pek

1 Münir Aktepe, "Babadağı", Türkiye Diyanet Vakfı islam Ansiklopedisi (DiA), Cilt IV, Ankara, 1991, s.372.

2 Turan Gökçe, "Babadağı Kasabasının XIX. Ortalarındaki Sosyal ve Ekonomik Yapısı", Tarih incelemeleri Dergisi, Cilt XXV, Sayı 1, 2010, S.155-190.

3 Yücel Öztürk, Özü'den Tuna'ya Kazaklar-1, Yeditepe Yayınevi, İstanbul, 2004, s.46.

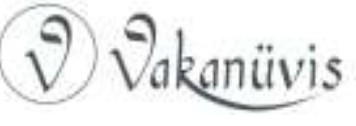


çok yerine yaptığı seyahatleri de mevcuttur. Ancak Balkanlar, özellikle Kırım ve Macaristan coğrafyası çok sık seyahat ettiği bölgelerdir. Onun Kırım Hanlığı'na yaptığı seferleri daha bir heyecanla anlattığını söylemek mümkündür. Kırım Hanlığı ile ilgili metinleri, onun bu bölgeye yakınlık hissettiği ve duygusal olarak bağlandığı izlenimini vermektedir. Eflak, Boğdan, Erdel, Kazak ve Kırım bölgesine yaptığı gezilerde birçok kez Babadağı'nı görme fırsatı bulmuştur. Bu nedenle Babadağı ve çevresiyle ilgili geniş malumat vermiştir.

Şehri pek çok kez ziyaret eden Evliya Çelebi, seyahatnamesinde verdiği bilgilere göre şehri ilk kez 1640 yılında ${ }^{4}$ yılında ziyaret etmiş ve şehirde çok fazla vakit geçirmeden aynı yıl İstanbul'a geri dönmüştür. Şehir ikinci kez 1649/1650 yılının Eylül ya da Ekim ayında ziyaret eden Evliya şehirde yaklaşık on ay kalmış ve aynı yıl İstanbul'a geri dönmüştür. Bu ziyareti esnasında kendisine Babadağı şehrinin voyvodalığı ve zahire bahası ihsan edilmiştir. ${ }^{5}$ Şehri üçüncü kez 1657 yılında ziyaret eden Evliya bu ziyaretinde kendisine tekrardan şehrin voyvodalığı ve zahire bahası ihsan edilmiş ve şehirde yaklaşık olarak on yedi ay konaklamıştır. ${ }^{6}$ Bu sebeple Evliya Bababadağı ve ona bağlı olan kasabaları da gezerek görevini yerine getirmiştir. Son olarak ise 1667 yılında şehre gelen Evliya şehrin gideceği yol üzerinde bulunması nedeniyle de burada yaşayan bir akrabasına uğramış ve kısa bir ziyaret gerçekleştirmiştir. ${ }^{7}$ Şehri pek çok kez ziyaret etmesinden dolayı verdiği bilgiler oldukça zengindir. Şehri her ziyaret edişinde Sarı Saltık'ı hatırlayan ve okuyucusuna hatırlatan Evliya, şehri adeta Sarı Saltık ile özdeşleştirmiştir.

Evliya Çelebi gibi seyahati doğrudan amaç edinenlerin yanı sıra farklı görevlerle yola düşmüş seyyahlar da bu şehre uğramıştır. Bunlardan biri de İbrahim Hamdi'dir. Bartınlı Es-seyyid İbrahim Hamdi

${ }^{4}$ Evliya Çelebi b. Derviş Mehemmed Zılli, Evliya Çelebi Seyahatnamesi Topkapı Sarayı Kütüphanesi Bağdad 304 Numaralı Yazmanın Transkripsiyonu-Dizini, Haz: Zekeriya Kurşun, Seyit Ali Kahraman, Yücel Dağlı, 2.Kitap, Yapı Kredi Yayınları, İstanbul, 2006, s.74.

${ }^{5}$ Evliya Çelebi Seyahatnamesi, Cilt III, s.188.

${ }^{6}$ Evliya Çelebi, Seyahatnamesi, Cilt V, s.106.

${ }^{7}$ Evliya Çelebi, Seyahatnamesi, Cilt VIII, s.22.

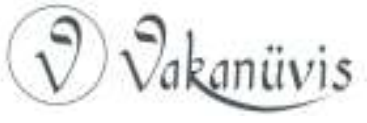


Efendi XVIII. yüzyılda yaşamış önemli bir coğrafyacıdır. ${ }^{8}$ Ibrahim Hamdi Efendi kaleme aldığı Atlas isimli eserinde hem Osmanlı memleketleri hem de Coğrafi Keşifler sonrasında keşfedilen Amerika gibi yeni ülkeler hakkında bilgiler vermektedir. ${ }^{9}$ ibrahim Hamdi'nin Atlas'ı iki ciltten oluşmaktadır. Fakat ilk cildi kayıptır. ${ }^{10}$ Eserin ikinci cildinde Mısır, Afrika, Amerika ve Avrupa ülkeleri hakkında bilgiler mevcuttur. Eserin ikinci cildi aynı zamanda Balkan coğrafyasına dair de bilgiler sunmaktadır. ${ }^{11}$ Yaşamının büyük bir kısmını sınır boylarında geçiren İbrahim Hamdi'nin bu şehri pek çok kez ziyaret etmiş olabileceğini düşünüyoruz. İbrahim Hamdi de Atlas isimli eserinde Balkan coğrafyasına dair birçok bilgi sunmaktadır. ${ }^{12}$ Ancak onun verdiği bilgiler daha çok özet ve klasik İslam ve Osmanlı coğrafyacıları tarzında sınırlandırılmış ya da özetlenmiş bilgilerden oluşur. Onun yetiştiği ve yaşamının büyük bir kısmını geçirdiği iki önemli serhad bölgesi olan Tımışvar ve Hotin ile ilgili verdiği bilgilerin dahi çok detaylı olmayışı bize bunu göstermektedir. İbrahim Hamdi şehri 1737-1738 yılında ziyaret ettiğini söylemiştir. ${ }^{13}$

Evliya Çelebi bir seyyah olarak şehri değerlendirirken ibrahim Hamdi ise İslam Osmanlı coğrafya yazım geleneğine sadık kalarak ve özet bilgiler vermekle yetinmiştir. Dolayısıyla iki Osmanlı münevverinin şehirleri anlatma üslubu ve içerikleri birbirinden oldukça farklıdır. Evliya Çelebi daha tafsilatlı, insan ve toplum hayatını yansıtan, şehri tasvir eden ve anlatısını renkli hikâyelerle destekleyen bir metin

8 Hasan Hüseyin Yılmaz-Ünal Yıldırım, Bartınlı İbrahim Hamdi'nin Atlas'ına Göre Bulgaristan'daki Bazı Yerleşmelerin Beşeri ve Ekonomik Özellikleri, Balkan Studies Geography and Geostrategy I, Ed. Deniz Ekinci, İstanbul, 2011, s.548.

9 Ömer Bıyık, Bartınlı Es- Seyyid İbrahim Hamdi Efendi'nin Atlas'ında Eflak-Boğdan (Memleketeyn), Ed. Zafer Gölen, Balkan Tarihi, Cilt II, Osmanlı Mirasını ve Türk Kültürünü Araştırma Derneği Yayınları I, 2016, s.263.

10 Mahmut Ak, "ibrahim Hamdi", Türkiye Diyanet Vakfı Islam Ansiklopedisi (DiA), Cilt 21, Ankara, 2000, s. 314.

11 Ömer Bıyık, a.g.m., s.263.

12 Mehmet Yaşar Ertaş, İbrahim Hamdi'ye Göre Silistre'den Vidin'e Tuna Kıyısındaki Osmanlı Şehirleri, Osmanlı ve Cumhuriyet Dönemi Türk-Bulgar iliş̧kileri Bildirileri, Eskişehir, 2005, s.244.

13 Cengiz Orhonlu 1737 yılında onun Babadağı'nda olduğunu belirtmiştir. Cengiz Orhonlu, "XVIII. Yüzyılda Osmanlılarda Coğrafya ve Bartınlı İbrahim Hamdi'nin Atlası, Tarih Dergisi XIV/19, 1964, S.123.

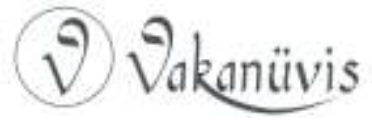


oluşturmuş iken İbrahim Hamdi yalın bir üslup kullanmış ve sınırlı bilgi vermekle yetinmiştir.

Üslup farklıığının yanı sıra iki seyyahın Babadağ’a dair verdikleri bilgiler de farklıdır. Seyyahların şehirle ilgili anlatıları, hem içerik hem de şehirle ilgili çizilen görüntü açısından değişiklik gösterir. İçerik ve üslup açısından farklılıkları olsa da hem Babadağı'nın farklı gelenekleri temsil eden iki Osmanlı seyyahı tarafından nasıl algılanıp anlatıldığını hem de iki ayrı dönemde şehrin yapısında ne gibi değişikliklerin olduğunu göstermesi açısından önem arz etmektedir.

$\mathrm{Bu}$ tür şehirlere yönelik bilgi edineceğimiz kaynakların sınırlılığı sebebiyle birbirinden üslup ve içerik bakımından farklı anlatımlara sahip iki eserin yaklaşık yüzyıla yakın bir süre geçmiş olsa da bir şehri iki yazar üzerinden anlatmak; hem karşılaştırma yapma imkânı vermektedir hem de o şehrin zaman içerisinde Osmanlı Devleti tarafından nasıl tanımlandığını, hangi yönüyle öne çıktığını, o şehirle ilgili bahsedilmesi gereken şeylerin neler olduğu konusunda bize fikir verecektir.

Ibrahim Hamdi, Babadağı şehrini tanıtmaya öncelikle coğrafi konumundan başlamıştır. Ardından ise yer aldığı enlem ve boylam bilgilerine yer vermiştir. Şehrin topoğrafyasına değinen yazar, şehri iki bayır arasında bulunan bir bataklık olarak betimler. ${ }^{14}$ ibrahim Hamdi verimli topraklarına dikkat çekerek üzüm bağlarından ve bereketli üzümlerinden bahseder. Bu bolluğun kıymetinin bilinmediğini düşünen İbrahim Hamdi şehir halkının tembelliğinden dem vurur. Ahalinin günlük gıdaları içinde sebzevat cinsi bir şey bulunmadığını söyleyen Ibrahim Hamdi onların sadece ekmek yediklerini ve bulurlarsa da et yediklerini aktarır. İbrahim Hamdi'ye göre bereketli topraklara sahip olmalarına rağmen halkın sebze ağırlıklı beslenmemesi onların "bi arif" kişiler olmasından kaynaklanmaktadır. Tembel diye nitelediği bu halkın geçimini eşkıyalık faaliyetleri ile sağladığını da ifade etmektedir. Bu güzergâhtan geçenleri veyahut şehre misafir olarak konaklamaya

\footnotetext{
${ }^{14}$ kırk yedi derece tûl ve kırk beş derece arzda otuz sekiz derece inhirâf-ı kıble ile iki bayır arasında sazlık ve bataklık düz dere içinde hayli vâsi' bir şehir olup. Bkz. Bartınlı İbrahim Hamdi, Atlas, Süleymaniye Kütüphanesi Esad Efendi, 2044, vr.177b.
}

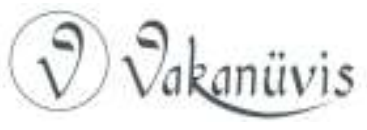


gelenler arasından kendilerince katle münasip gördüklerini öldürüp soyduklarını ve geçimlerini bu şekilde temin ettiklerini ifade eder. ${ }^{15}$

Evliya Çelebi'nin ise, Ibrahim Hamdi'nin aksine şehri ve şehrin halkı hakkında olumlu kanaatlere sahip olduğu görülür. Evliya Çelebi de şehrin bereketli olduğundan bahseder. Bu sebeple de şehre gelen giden misafirin çok olduğunu yazar. Onun ifadesiyle şehir halkı "halkı garip dostu, fakirleri sever ve Ehl-i Beyt muhibbidirler."16 Aynı zamanda Evliya Çelebi'nin serhad şehirlerinde bulunduğu dönemlerde bu bölgelerin hareketli doğasından etkilendiği ve anlatılarının coşkulu olduğu görülür.

Ibrahim Hamdi ise Babadağı halkını pek de dindar bulmamaktadır. Hatta kuşluk vaktinde tıpkı eşekler gibi uyuduklarını ve namaz kılmadıkları için cami kapılarının kapalı olduğunu söyler. Halkın namaz kılmaması nedeniyle ỉbrahim Hamdi Babadağı'nı İslam şehrine benzetememiştir. Her ne kadar İbrahim Hamdi şehir halkının namaz kılmamasına sitem etse de Babadağı halkı bu duruma bir çözüm bulmuştur. Şehir halkının kılmadıkları namazlarının borçlarını ödemek için Ramazan ayında şehrin kadısına birer kuruş "cizye" verdiklerini söyler. Burada ilginç olan İbrahim Hamdi'nin borçlarını ödemek isteyen halkın, kadıya verdikleri ücrete cizye adını vermesidir. Bilindiği gibi cizye hukuki bir terim olup gayrimüslimlerden alınan şer'i bir vergidir. Burada İbrahim Hamdi'nin cizye kelimesini bilerek kullanmış olabileceği akla gelmektedir. Çünkü o namaz kılmadıkları için Babadağı halkını kınarken ağır ifadelerle onları suçlamaktan çekinmemiş ve hatta onlardan bi-namaz kefere olarak bahsetmiştir. Dolayısıyla Bartınlı İbrahim Hamdi, Babadağı halkını genel olarak "kafirden" farklı görmemekte, onlar hakkında doğrudan kefere kelimesini kullanmakla kalmayıp, kadıya hayır yapmak üzere ödedikleri paraları da cizye olarak adlandırmaktadır. $\mathrm{O}$, şehir halkının Ramazanda ${ }^{17}$ borçlarını ödemek için

\footnotetext{
${ }^{15}$ Atlas, vr. 178a.

${ }^{16}$ Evliya Çelebi Seyahatnamesi, Cilt III, S.206.

17 Kendisinin Ramazan ayında burada bulunuyor olması karşılaştığı farklı bir duruma istinaden farklı şekilde anlatmış olabilir. Şehir halkı Ramazan ayı olması nedeniyle hayır hasenat maksadıyla içinde bu parayı vermiş olabilir. Fakat İbrahim Hamdi bu durumu farklı yorulmayarak bir tür namazlarına kefaret olmak üzere para verdiklerini düşünmüş olmalıdır.
}

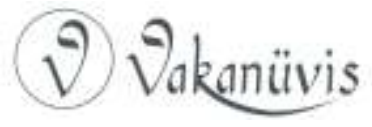


şehrin kadısına birer kuruş verdiklerini söylüyor. Ancak normalde Hristiyanlıkta olduğu gibi bir günah çıkarma seremonisi İslam'da mevcut değildir. Muhtemelen Müslümanlar, kadıya ramazan ayı olması nedeniyle hayır hasenat yapmak üzere yardım da bulunuyor olmalılardır. Cizye Kelimesini "karşılığını vermek" "ödemek" anlamına geldiğini düşündüğümüzde, tüm yukarıdaki yorumlara karşılık doğrudan İbrahim Hamdi'nin böyle bir teşbih yapmaksızın doğrudan sözlük anlamını kullanmış olabileceği de göz ardı edilmemelidir. ${ }^{18}$

Ibrahim Hamdi Babadağlılardan bahsederken yukarıda da vurgulandığı gibi çok verimli olmasına rağmen buraları işlemedikleri için onları tembellikle suçlamıştır. Onların yaşam tarzı haline gelen bu tembelliğin ahlaksız bir boyutu olduğuna da dikkat çekmiştir. Bartınlı'ya göre ovalarını işlemeyen tembel Babadağlılar, dağlık bir bölgede yaşamalarına rağmen, dağlardaki imkânları da değerlendiremiyorlardı. Onun bir asker olarak belki de birkaç ay kışlamak maksadıyla yaşadığı Babadağ'da karşılaştığı ve ahlaksız bir durum olarak aktardığı manzara gerçekten dikkat çekicidir. Çünkü o dağlardan odun kesip askere satabilecek durumda olmalarına ve öküzleri bulunmalarına karşın erkeklerin dağa çıkıp odun toplayıp bunu sadece askere satmaları durumunda bile gelir elde edebileceklerinin altını çizerken, Onların bunun yerine ahlaksız bir yola tevessül ettiklerini söylüyor. İbrahim Hamdi, değil askere odun satarak para kazanmak, kendi odun ihtiyaçlarını askerden talep etmek üzere eşlerini ve kadınlarını kullandıklarını söylemektedir. Muhtemelen Babadağı'nda kaldığı süre boyunca karşılaştığı bir manzara olmalı ki kadınların odun ihtiyacı için askerlerden adeta dilenerek odun istediklerini ifade etmiştir. Fakat daha da ileri giderek bu kadınların yardım karşıı̆ında askerlerle gayrimeşru bir ilişki içerisine girmeyi kabullendiklerini de belirtmiştir. Bu ahlaksızlığın yaygınlığını bizatihi kendisi kışlakta yaşadığı için görmüş olmalıdır. Ahlaksızlık olarak gördüğü bu durumu kuvvetlendirmek için verdiği örnek ise bir hayli ilginçtir. O, askerlerle iç

18 Mehmet Erkal, "Cizye”, Türkiye Diyanet Vakfı İslam Ansiklopedisi (DiA), Ankara, 1993, Cilt VIII, S.42.

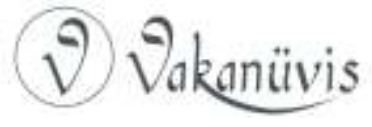


içe olan bu kadınlardan dolayı kışlayan askerlerin pek çok kadını hamile bırakıp geride pek çok çocuk bıraktığını da söylemiştir. ${ }^{19}$

İbrahim Hamdi'nin Babadağı ile ilgili verdiği bilgilere topluca bakıldığında, şehrin çok verimli ovalara ve şehri besleyecek pek çok olanağa sahip olmasına rağmen fakir, bakımsız, işlenmemiş bir şehir görünümü çizmiş diğer taraftan şehirlileri de tembel, dinden uzak ve ahlaksız olarak nitelendirdiği söylenebilir. Buna karşın Evliya çok farklı bir Babadağı resmi ve imgesi çizmektedir. İbrahim Hamdi'nin tasvirlerini gördüğümüzde kasvetli, bakımsız bir şehir göz önüne gelirken yaklaşık yüz yıl önce Babadağı'nı ziyaret eden Evliya Çelebi'nin daha canlı, zengin ve renkli bir şehir fotoğrafı çektiğini söyleyebiliriz.

Ibrahim Hamdi şehre dair çok yukarıda bahsettiğimiz ögeleri görmüş ve bunlardan bahsetmiş ve bunları öne çıkarmıştır. Bir şehir anlatısı olmasına rağmen örneğin o şehirdeki kaleler, şehrin camilerinden sokaklarından bahsetmemiş veyahut bahsetme gereği duymamıştır. Bahsettikleri ise oldukça kısadır. Onun zihnindeki Babadağı'na ilişkin tasavvurda bu ögeler yer almamış da denilebilir.

Evliya, şehrin genel görünümünden bahsederken dahi zihnimizde oluşan tablo bu beldenin zengin ve gösterişli bir yer olduğudur. "Hepsi kiremitli ve şindire tahtası ile örtülü tam üç bin adet altlı üstlü kargir yapı yüksek saraylar ve diğer çeşitli evlerdir." ${ }^{20}$ Şehre zenginlik katan pek çok yapıdan bahseden Evliya Çelebi özellikle II. Bayezid'in şehrin fethi esnasında yaptırdığı camiye değinmeden geçmez. Evliya Çelebi Ulu camiyi tarif ederken caminin iç kısmına ait olan "bukalemun nakışlı" gül tavanına değinmiş ve camiye gelen cemaatin kalabalık olduğundan ve cami imamının veli mertebesine sahip dindar biri oluşundan bahsetmiştir. Bu örnekten de anlaşılacağı üzere Evliya Çelebi'nin anlattığı Babadağı şehri ile İbrahim Hamdi'ninki birbirinden oldukça farklıdır. İbrahim Hamdi'nin aksine Evliya Çelebi cemaatin kalabalıklığından söz etmektedir. Evliya Çelebi sadece camilerden değil şehirde bulunan medrese, han, hamam, kervansaraylar, dükkanlar, bekar hanları, tekkelerden de kısaca bahseder. Bu yapılardan

${ }^{19}$ Atlas, vr. 178a.

${ }^{20}$ Evliya Çelebi Seyahatnamesi, Cilt III, S.205.

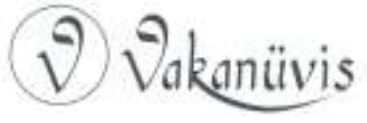


bahsederken yapmış olduğu II. Bayezid vurgusu ise gözden kaçmamaktadır. ${ }^{21}$

İbrahim Hamdi, halkın beslenme biçimini açıkça yazmış, halkın et ve hububata dayalı olan beslenme kültüründen bahsetmiştir. Evliya ise halkın doğrudan ne yiyip ne içtiklerini anlatmamış ancak buranın üzüm, beyaz ekmek ve yoğurdunun; içeceklerden ise üzüm şırasının, bal şerbetinin ve tatlı bozasının meşhur olduğundan bahsetmiştir. Şehrin sularından da bahseden İbrahim Hamdi "lakin suları kuyudan olmağla gâyet alçak ahşamdan koğaya korlar sabah nazar eylesek yosun bağlamışdır" şeklinde olduğunu belirterek şehrin suyunu beğenmediğini ifade etmiştir. ${ }^{22}$

Evliya'nın anlattığı yerler içerisinde mesiregâhlara ve gezilecek yerlere özel önem verdiği bilinmektedir. Burada da Evliya halkın rağbet ettiği mesire yerlerinden biri olan Dede Saltık korusunu zikreder. Ancak onun metninde bilinçli olarak yapmış olduğu Sarı Saltık vurgusu düşünüldüğünde neden en önemsediği mesiregâhın da Dede Saltık korusu bir nebze de olsa ortaya çıkmaktadır. Verdiği tüm bilgilere karşın aslında Evliya Babadağı şehrini anlatırken merkeze aldığı esas unsur Sarı Saltık'tır. Bu nedenle Babadağı şehrini Sarı Saltık ile özdeşleştirerek verdiği çok belirgindir. Bu anlamda Sarı Saltık'ı Babadağı'nın her köşesinde görmek mümkündür.

Anlatıcıların Babadağına dair gözlemlerini aktaran iki seyyahın edebiyat, sanat, estetik anlayışları metni inşa etmedeki teknikleri, eğitim durumu, düşünce dünyaları, görüşleri iki farklı Babadağı anlatısının ortaya çıkmış olabileceğini düşündürmektedir. İki seyyahın şehir hakkındaki izlenimlerinde karşılaşılan bu belirgin farklılı̆̆ın, zaman içinde farklı coğrafyadan gelen insanların etkisiyle şehrin demografik niteliğinin ve görünümünün değişmesinden kaynaklandığı da düşünülebilir.

İbrahim Hamdi, kayıpların ve Osmanlı mağlubiyetinin yaşandığı bir dönemde yaşamış ve kayıpları bizatihi görmüştür. Aynı zamanda onun asker oluşu bu kayıpları çok daha kolay ve çabuk içselleştirmesine

${ }^{21}$ Evliya Çelebi Seyahatnamesi, Cilt III, s.205.

${ }^{22}$ Atlas, vr. 177b.

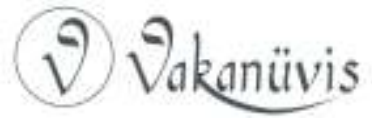


neden olmuş olabilir. Belki de bu nedenle halka karşı tutumu çok sert olmuştur. Halkın kendini bırakması fetihleri daha da kolaylaştırmış olabilir. Onların mücadele etmeyen tavrı İbrahim Hamdi'yi bu anlamda kızdırmış olabilir. Çünkü İbrahim Hamdi uzun dönemler serhad şehirlerinde yaşamını sürdüren biri olarak bu mücadelenin içinde olmuştur. Bu nedenle halkın tutum ve davranışları onu oldukça rahatsız etmiştir.

Evliya Çelebi'nin seyahatnamesinde Babadağı şehri Balkanlarda İslam'ın yayılmasını sağlayan derviş rolü ile Sarı Saltık etrafında kurgulanmıştır. Evliya Çelebi, onun Balkanlarda üstlenmiş olduğu rolü kimi zaman doğrudan, kimi zaman ise dolaylı olarak Bayezid üzerinden anlatmıştır. Bu anlamda Evliya Çelebi'nin kaleme aldığı Babadağı şehri anlatısının, gezip gördüğü ve hikaye ettiği başka yerlerden farklı olduğunu söylemek mümkündür. Evliya, gördüğü yerleri anlatırken genellikle varsa şehrin kalesi, ardından halkı, konuşulan diller, kültür yapısı, kıyafetler, şehirde yetişen bitkiler ve şehirde bulunan mimari yapılardan bahseder. Babadağı şehrinde de bu hususlardan söz etmekle beraber Sarı Saltık figürünün anlatıda ön plana çıktığı görülür. $\mathrm{Bu}$, anlatıma mistik bir hava da kazandırmıştır. Burada sorulması gereken ilk soru şudur: Evliya Çelebi Sarı Saltıktan neden bu denli yoğun şekilde bahsetmiş, şehri neden Sarı Saltık'ı merkeze alarak anlatmayı tercih etmiştir?

Balkanlara göç ederek bu bölgenin müslümanlaşmasını sağlayan önemli dervişlerden biri olan Sarı Saltık ${ }^{23}$ Müslümanlar arasında itibar sahibiydi. O, zamanla Hıristiyanların da teveccühünü ve saygısını kazanmıştır. Onun, her iki dinin mensuplarınca bu derece saygı görmesi ve onun İslam dinini yaymadaki üslubu, hem kendi döneminde hem de sonraki dönemlerde onun gerçekten müslüman bir derviş mi yoksa Hıristiyan bir rahip mi olduğu yönünde tartışmalar doğurmuştur. Evliya Çelebi de Babadağı anlatısında bu tartışmaya dahil olmuştur. Evliya Çelebi'nin Babadağı şehrini anlattığı kısım incelendiğinde Sarı Saltık'ın bir rahip değil Müslüman bir derviş olduğunu kanıtlamaya çalıştığı söylenebilir. Hatta denilebilir ki Babadağı şehrini anlatmak Evliya Çelebi için Sarı Saltık hakkındaki fikirlerini anlatmanın bir zemini olmuştur.

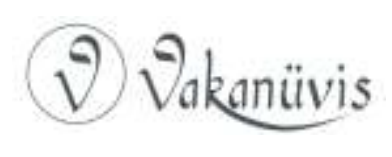


Eserinin Babadağı bölümünü bu anlamda bir vasıta olarak kullanan Evliya Çelebi, anlattığı hikayeler ile metnini zenginleştirilmiş ve okunması zevkli bir hale getirmiştir. Bu anlamda Evliya Çelebi için Babadağı'nın anlamı Sarı Saltık'ın dervişliği ile doğrudan bağlantılıdır.

Sarı Saltık hakkından yazılmış pek çok eser bulunmaktadır. Yazılan eserlerde Sarı Saltık kimi zaman üstün güçlere sahip bir derviş kimi zaman sıradan biri olarak karşımıza çıkmaktadır. Her eser onu kendi çağının siyasi, sosyal ve kültürel altyapısına ve özellikle dönemin siyasi ortamına göre tanımlamıştır. Evliya Çelebi de bunlardan biridir. O, Babadağı şehrini anlatırken Sarı Saltık'ı oldukça önemsemiş, ulemanın ve devlet otoritesinin Sarı Saltık ile ilgili olumsuz görüşlerine karşılık verme zemini yakalamıştır. ${ }^{24}$ Ancak bu durum sadece Evliya Çelebi'nin yaptığı bir durum değildir. Sarı Saltık'ın ölümünün ardından onun hakkında yazılmış eserler onu siyasi, sosyal ve kültürel bir figür olarak kendi kültürlerine katmaya çalışmışlar ve yazdıkları eserlerde onun taraf olmasını sağlayarak kendi fikirlerini kuvvetlendirmeye çalışmışlardır. Bu nedenle Evliya Çelebi'nin Babadağı ziyareti Sarı Saltık ile ilgili fikirlerini paylaşma adına önemli bir ziyarettir.

Saltıkname' $\mathrm{de}^{25}$ anlatıldığı kadarıyla Sarı Saltık kimi zaman kiliselerde rahip kılı̆ı̆na girmiş ve Hıristiyanlar ile dinleri hakkında tartışmalar yapmıştır. Aynı zamanda onun İncil okuyarak Hıristiyan rahipleri alt ettiğinden bahsedilmektedir. ${ }^{26}$ Ancak onun İslam dinini yaymadaki kullandığı bu yöntem ve tarz o öldükten sonra tartışmalara neden olmuş olmalıdır. Çünkü Kanuni döneminin meşhur şeyhülislamı Ebussuud Efendi onun bir keşiş olduğuna dair fetva çıkarmıştır. Bu

${ }^{24}$ Sarı Saltık'ın faaliyetleri onun heterodoks bir derviş olarak tanımlanmasına sebep olarak ulema ve devlet otoritesi arasında rahatsızlık durulmasına yol açmıştır. Bkz. Helga Anetshofer, "Seyahatname'deki Sarı Saltık Menkıbeleri ve Bektaşi Sözlü Rivayeti" (Ed. Nuran Tezcan), Doğumunun 400. Yılında Evliya Çelebi, T.C. Kültür ve Turizm Bakanlığı, Ankara, 2011, s.293.

${ }^{25}$ Cem Sultan Sarı Saltık'ın türbesini ziyaret ettikten sonra menakıbını dinlemiş ve onun hakkında bir eser kaleme alınmasını istemiştir. Bu eser Ebulhayr Rumi'nin yazdığı Saltuknamedir. Bkz. Machiel Kiel, "Sarı Saltuk", Türkiye Diyanet Vakfı islam Ansiklopedisi (DiA), Cilt 36, Ankara, 2009, s.147-148.

26 Ahmet Yaşar Ocak, Osmanlı Sufiliğine Bakışlar-Makaleler, Incelemeler, 2010, İstanbul, Timaş Yayınları, s.20.

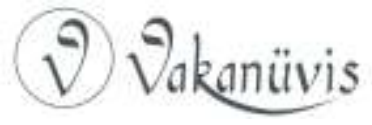


fetvayı çıkarmasının nedeni ise Kanuni'nin bizzat kendisidir. 1538 yılında Kanuni sefer dönüşü uğradığı Babadağı şehrinde Sarı Saltık'ın türbesini ziyaret etmiştir. İstanbul'a dönüşünün ardından Ebussuud Efendi'den Sarı Saltık'ın erenlerden olduğuna dair bir fetva çıkarmasını istemiş ancak Ebussuud buna itiraz etmiş olmalı ki fetvası şu yönde olmuştur: "Sarı Saltık riyazet ile kadid olmuş bir keşişdir" 27 Devlet otoritesinin ve 16 yüzyıl ulemasının Elbette Evliya Çelebi'nin bu fetvadan haberi vardır. Onun Hıristiyan bir keşiş olduğu hakkında çıkan bu fetvadan Evliya Çelebi'nin haberinin olmaması mümkün değildir. Ancak o bu fetvadan bahsetmeksizin hem ulamayı temsilen Ebussuud Efendi'ye hem de devlet otorisinin Sarı Saltık hakkındaki düşüncelerine doğrudan yanıt vermiştir. ${ }^{28}$ "Belî, Leh vilâyetinde Daniska iskelesinde Saltık nâmında bir ruhbân var idi, anı varup dîne da'vet edüp islâm kabûl etmediğinden Saltık Bay, Saltık ruhbânı hücresinde katl edüp anın libasıyla mülebbes olup nihânîce niçe sene râh-ı dalâletde kalan mahlûk-ı Hudâyı İslâm ile müşerref edüp seyâhat ile nâm verüp Babadağı'nda civâr-ı rahmete sene (---) târîhinde revâne oldu, deyü niçe kütüb-i tevârîhde ve mu'temed Yazıcızâde menâkibinde mestûrdur."29 diyerek Sarı Saltık'ın tarafında olduğunu belli etmiş ve onun hakkında ortaya atılan iddialara bir nevi cevap vermiştir.

Evliya Çelebi şehri anlatırken Sarı Saltık'tan pek çok kez bahsetmiştir. O, Sarı Saltık'a diğer kaynaklarda bulunmayan bir isim dahi vermiştir. Bu isim Evliya Çelebi'nin Sarı Saltık'ı büründürmek istediği derviş-evliya karakteri ile yakından ilişkilidir. Evliya Çelebi'nin ona verdiği isim Sarı Saltık Muhammed Buhari'dir. Bu isimle birlikte kimi zaman ise Saltık Bay ismini de kullanmıştır. "Bay" kelimesi Orta Asya Türk Devletlerinde han soyundan gelenler için kullanılan bir kelimeydi. Evliya Çelebi Sarı Saltık'ın soyluluğunu vurgulamak için bu ismi kullanmış olmalıdır. ${ }^{30}$ Her iki isim de Evliya Çelebi'nin Sarı Saltık'ın bir rahip olduğunu düşünen çağdaşlarına karşı tutumun, isim üzerinden anlatılmaya çalışılmasıdır. Evliya kullandığı isim ile onun $\mathrm{Hacı}$

\footnotetext{
27 M. Tayyib Ökiç, "Sarı Saltık'a Ait Bir Fetva”, AÜiFD, Cilt I, Ankara, 1952, s.56.

28 Helga Anetshofers a.g.m., 293.

${ }^{29}$ Evliya Çelebi Seyahatnamesi, Cilt III, s.206.

30 Bazı kaynaklarda Sarı Saltık'ın çoban olduğunu hakkında rivayetler vardır. Evliya Çelebi muhtemelen bu fikri kırmak için "Bay" sıfatını kullanmıştır.
}

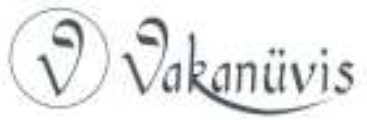


Bektaş Veli gibi Horasan erenlerinden olduğuna dikkat çekmiş aynı zamanda Sünniliğine atıf yapmak için Muhammed ismini kullanmıştır. ${ }^{31}$

Evliya Çelebi'nin yaşadığı dönem Kadızadeliler gibi sert dini tutumların sergilendiği bir dönemdir. Ancak Evliya Çelebi bu katı geleneğin izinde olmamış ve Sarı Saltık'a sahip çıkmıştır. Dönemin şekilci ve sert dini anlayışına karşı o hoşgörüsü ile Sarı Saltık'ın tarafında bulunduğunu belli etmiştir. Bu Evliya Çelebi'nin karakteri nedeniyledir. Çünkü o kimi zaman kafirin ibadethanesini bile hayranlıkla izleyebilen, dinin yasakladığı içkiyi hoş karşılayabilen bir karakterdedir. Dolayısıyla onun karakterinde olan birinin Sarı Saltık ile bağ kurması ve onu sahiplenmesi gayet doğaldır.

Evliya, Babadağı şehrini Sarı Saltık merkezinde anlatırken, II. Bayezid'i de bu merkeze çekmiştir ve Babadağı'nın ikinci sahibi ve mimarı olarak II. Bayezid'e işaret etmiştir. ${ }^{32}$ Şehrin daha çok mistik yönünü vurgulayan Evliya Çelebi, II. Bayezid'in veli bir padişah oluşunu önemseyerek ona dair menkıbeler de anlatmıştır. Burada II. Bayezid ile ilgili menkıbeler anlatmasının iki nedeni vardır. Birincisi; her ne kadar şehir Çelebi Mehmed tarafından fethedilse de imar faaliyetleri Bayezid tarafından yapılmıştır. Şehrin imar edilmesinin yanında Sarı Saltık'ın kaybolan mezarı Evliyanın anlattığına göre Bayezid tarafından rüya yolu ile bulunmuştur. Rüya ile yapmış olduğu kurgu vasıta ile o, Bayezid ve Sarı Saltık'ın dervişliğini bağdaştırarak Sarı Saltık'ın meşruiyetini Bayezid'e dayandırmak istemiştir. Hatta Evliya bu kurguyu güçlendirmek ve sadece Bayezid'e dayandırmamak için onun akıl hocası olan Karaşemseddin'i de kullanmıştır.

\footnotetext{
31 Helga Anetshofer, a.g.m., s.294.

32 "Sultan Bayezid, Hırsova'ya tabi Baba kasabası mahsulünden senevi 9172 ve Baba Kasabası'ndaki Hamam-ı Cedid mukataasından 27.999 akçeden müteşekkil 37.171 akçeyi Saru Saltuk Zaviyesi ve Baba Kasabası'nda bina ettirdiği camiine akar olarak vakfetmiştir. Hâsılın, müderrise günde üç, talebe ve bevvabiyeye 21, tevliyete 15, nezarete beş, kitabete üç, cibayet maa muallime üç, hitabet ve imamete altı, müezzinlere yedi, kayyuma iki, ferraşa iki, tarife bir, devirhanâna üç, ser-mahfele iki, cüzhanâna beş, meremmetçiye iki, şem ve hasıra bir, harc-ı taam-ı zaviyeye 25, nezârete iki akçe şeklinde cihet olarak dağıtıldığı anlaşılmaktadır. Kara Hasan bin Yakub da senelik hâsılı 540 akçe olan üç bab mağazayı cüz tilâveti için vakfetmiştir." Şehri şenlendiren II. Bayezid'in faaliyetleri için Bkz: TADB. TTD. EV. 561, v. 308a.
}

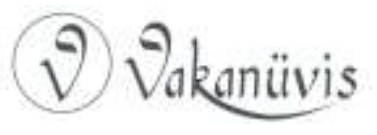


Sarı Saltık'ın mezarının bulunması ise Bayezid'in 1484 yılında Kili ve Akkirman fetihleri dönüşünde Babadağına uğraması ile gerçekleşmiştir. Şehre gelen II. Bayezid neden bu şehre Babadağı isminin verildiğini sormuş ve şehrin pirlerinden cevaben Sarı Saltık'ın burada yaşamasından dolayı buraya Babadağı dendiği ancak onun türbesinin kafirler tarafından yıkılarak üzerine çöp ve pislik döküldüğü ve türbenin kaybolduğu cevabını almıştır. II. Bayezid çöplük olan yere gitmiş ve orada Karaşemseddin ile birlikte iki rekat namaz kılmışlardır. Ardından istihare niyetiyle ikisi birlikte uykuya dalmışlar ve ikisi de aynı rüyayı görmüşlerdir. Gördükleri rüyada Sarı Saltık sarı sakalı ve yeşil sarığı ile Bayezid'i hoş geldin diye karşılamış ve ona iltifatta bulunmuştur. Uykudan uyandıklarında gördükleri rüyayı birbirlerine anlatmadan tabir etmesi için yazıp şeyhülislama göndermişler ve şeyhülislam cevabında orada büyük veli bir zatın gömülü olduğunu ve hemen oraya bir türbe yapılmasını bildirmiştir. ${ }^{33}$ Kullandığı rüya motifi ile o Sarı Saltık'ın varlığını rüya yolu ile kanıtlamaya çalışmakta ve bunu Bayezid'i hikayenin içine dahil ederek yapmaktadır. Anlattığı rüyanın hemen ardından da Bayezid gibi veli ve ahiret padişahının böyle bir rüya görmesinin ne denli önemli olduğunu vurgulamıştır. ${ }^{34}$

Şeyhülislamın rüya tabirinin ardından Sarı Saltık'ın mezarının burada olduğuna kanaat getirilmiş ve türbenin yapımına başlanmıştır. Türbenin yapılmaya karar verilmesinin ardından ortaya üzerinde "Haza Kabru Saltık Bay Muhammed Buhari" yazılı olan bir sanduka çıkmış ve hemen buraya bir türbe ve cami yapılmaya başlanmıştır. ${ }^{35}$ Bu sırada Kili ve Akkirman fetihlerine çıkan II. Bayezid Babadağına uğradığı sırada bu fetihlerinden başarılı olarak dönmüş, dönerken yine Babadağı şehrini ziyaret etmiş ve kışı burada geçirmiştir. Burada geçirdiği vakti şehrin

33 Bayezid Sarı Saltık'ı rüyasında gördüğü esnada Sarı Saltık Kili ve Akkirman'ı hangi tarihte fethedeceğini söylemiştir. Ayrıca Bazyezid'in evlatlarının Mekke'ye ve Medine'ye sahip olacağı haberini de vermiştir. Bkz. Evliya Çelebi Seyahatnamesi, Cilt III, s.206-207.

${ }^{34}$ Imdi azîzim Bâyezîd-i Velî böyle mazanne-i kirâme pâdişâh-ı âhiret iken ilm-i bâtınla ana ma'lûm olmadı mı ki Saltık Sultân kim ola, eğer kem ola bir gümnâm olsa niçün bu kadar mâl-ı vakfullahı bed-nâm olan kimesne uğruna hebâ yire sarf ederdi. Bkz. Evliya Çelebi Seyahatnamesi, Cilt III, S.207.

${ }^{35}$ Evliya Çelebi Seyahatnamesi, Cilt III, S.207.

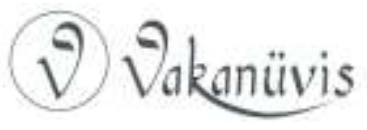


imar faaliyetlerine ayırmış, hayır hasenatlar yaparak sevabını Baba Sultan'a yani Sarı Saltık'a bağışlamıştır. Bu faaliyetlerinde ötürü Evliya'nın teveccühünü kazanan II. Bayezid veliliğini bu şekilde bir kez daha kanıtlamıştır.

Bahsi geçen türbeyi Evliya Çelebi eserinde detaylı bir şekilde tasvir etmiştir. Türbeyi ziyaret eden Evliya Çelebi için bu büyük bir şanstır. Çünkü burayı ziyareti esnasında o şu sözleri söylemiştir. "Hazreti Sarı Saltık sultanı ziyaret eyledik çok şükür şimdi görüp Hakka ibadet eyledik". Sarı Saltık gibi mübarek bir zatı ziyaretini Hakka ibadet sayan Evliya, buraya geldiği zaman ona "es-selamü aleyke ya ebi'l fukara" diye selam vererek türbeden içeri girmiş ve ruhu için Yasin-i Şerif okumuştur. ${ }^{36}$ Evliya Çelebi burayı oldukça gösterişli ve süslü bir şekilde anlatmıştır. Sarı Saltık'ın sandukasının yeşil bir örtü ile örtüldüğünü ve duvarların hüsn-ü hat yazılarıyla süslendiğini söyler. Rahleler üzerinde ise kimi padişahlar tarafından hediye edilmiş değerli Kuran-ı Kerimler olduğunu ve böyle Kuran-ı Kerimlerin ne Ayasofya'da ne Süleymaniye'de olmadığını yazar. Sandukanın başında ve ayakucunda ise çeşitli renklerde ve çok uzun buhurdan, şamdan ve gülabdanlardan ve başka hiçbir yerde bulunmayan avizeler olduğundan bahseder. Bunların dışında Sarı Saltık'ın hayatta iken kullandığı tuğ ve davulun da hala türbede bulunduğunu yazarak ona gazi-savaşçı sıfatı kazandırmak ister. Bu türbeyi anlatmaya ise dillerin yetmeyeceğini de eklemeden geçmez. ${ }^{37}$

${ }^{36}$ Evliya Çelebi Seyahatnamesi, Cilt III, S.207.

37 Kabr-i münevveresinin sebz-gûn sûf kaplı sütri etrâfında niçe hüsn-i hat kelâm-ı şerîfler rahleler üzre durur. Her biri birer pâdişâh-ı Cem-cenâbların hedâyâlarıdır kim İslâmbol'da Ayasofya ve Yenicâmi' ve Süleymâniyye'de eyle mushaflar yokdur. Ve başı ve ayağı ucunda âdem kaddi müzehheb ve mutallâ şem'dânlar vardır. Dahi etrâfında kat-ender-kat niçe yüz gûne şem'dân ve çerâğdân ve buhûrdân ve gülâbdân ve mermerler vardır. Ve ol kıbâb-ı pür-envâr içre gûnâ-gûn zî-kıymet ibret-nümûn âvîze-i maslûbâtlar var kim bir âsitâne-i ma'mûr [u] âbâdânda misilleri yokdur. Ve kabr-i münevverenin cânib-i erba'asında niçe bin hüsn-i hat kıt'alar ile ârâste ve dervîşân-ı zîşân pâlhengleriyle ve zerdeste ve keşkülleriyle pîrâste olmuş âsitânedir. Ve azîzün ser-i sa'âdeti tarafında zamân-ı sa'âdetlerinde isti'mâl etdikleri tuğ ve tabl [u] alem ve nefîr ü zil ü kudûmler hâlâ âmâdedir. El-hâsıl bu âsitânenin medhinde lisân kâsırdır. Bkz. Evliya Çelebi Seyahatnamesi, Cilt III, s. 202.

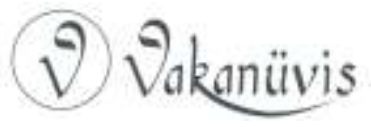


Evliya Çelebi'den yaklaşık seksen yıl sonra Babadağı şehrini ziyaret eden İbrahim Hamdi de Sarı Saltık olduğunu düşündüğümüz bir babanın türbesini ziyaret ettiğinden bahseder. Ancak onun bahsettiği türbe Evliya Çelebi'nin anlattığı türbe kadar bakımlı ve süslü değildir. İbrahim Hamdi Sarı Saltık isminden bahsetmeksizin şehre baba ismini veren bir kimsenin dağın tepesinde bulunan bir mezarı olduğunu öğrenmiş ve tırmanması güç olan bu mevkiye zorda da olsa tırmanarak mezarı ziyaret etmiştir. Ancak Evliya Çelebi'nin bahsettiği gibi herhangi bir türbe ile karşılaşmaz. İbrahim Hamdi sadece iki taşın bulunduğu sıradan bir mezardan bahseder. Hatta ayak ve başucunda bulunan taşların etrafı çalılarla sarılmış olduğunu ve bu çalılara şehrin hastalarının gelip kırmızı iplik ve beyaz bez parçaları bağladığını yazar. İbrahim Hamdi de ziyaret ettiği mezarın mübarek bir zata ait olduğunu vurgulamak istercesine rüya motifini kullanmıştır. İbrahim Hamdi mezarın bulunduğu yerin çok yokuş olmasından dolayı buraya güçlükle çıkmıştır. Ancak bu güçlüğün sonucunda o da Evliya Çelebi'nin II. Bayezid için anlattığı gibi bir rüya olmasa da tüm güçlüklere rağmen buraya ulaşmasının mükâfatını almışçasına bir rüya gördüğünden bahseder. Rüyasına biri zayıf ve diğeri şişman olan iki pir onun kaldığı konağa gelerek çok yaşlandıklarını ve bu nedenle güç hareket ettiklerini söylemiş ve İbrahim Hamdi'den özür dilemişlerdir. Diğer gün rüyasını şehir halkından birilerine anlatınca onlarda cevaben kim onun mezarını temiz bir niyet ve içtenlikle ziyaret ederse onun rüyasına girer diye tabir etmişlerdir. ${ }^{38}$

Her iki müellif de Babadağı'nda bulunan ermiş bir kişiye ait olduğu düşünülen bir mezarı ziyaret etmiştir. Ancak Evliya Çelebi daha kesin ifadeler kullanmış ve burada bulunan türbenin Sarı Saltık'a ait olduğunu pek çok kez vurgulamıştır. ${ }^{39}$ ibrahim Hamdi'nin bahsettiği ve Sarı Saltık'a ait olduğunu düşündüğümüz bu mezar ise Evliya'nın anlattığı türbeden daha farklıdır. Onun bahsettiği türbe Evliya Çelebi'nin anlattıklarının aksine daha sönük ve gösterişsizdir. Nitekim Ibrahim Hamdi de Evliya Çelebi gibi bir türbeden değil sadece bir mezardan bahsetmektedir. Bunun sebebi şehrin geçirdiği değişim ve

${ }^{38}$ Atlası, vr. $178 b$.

\section{(2) Valanivivis}


dönüşümdür. Sarı Saltık'a ait pek çok türbe bulunmaktadır. ${ }^{40}$ Bunlardan biri Babadağı'nda bulunan zaviyesidir. Babadağı'nda bulunan zaviyesi 1484 yılında II. Bayezid tarafından bir külliyeye dönüştürülmüştür. Ancak bu zaviye XVIII-XIX yılında Ruslar tarafından yapılan istilalarla yok olmuş ve 1828 yılında yeni bir türbe inşa edilmiştir. Tek kubbeli bu türbe 26 Ekim 2001 tarihinde ziyarete açılmıştır. ${ }^{41}$ Bartınlı İbrahim Hamdi'nin şehri ziyaret ettiği tarihte, zaviye yapılan istilalar ile yıkıma uğramış olmalı ki o, türbe cinsinden bir yapıdan bahsetmez.

Sarı Saltık ve II. Bayezid karakterleri Evliya Çelebi ile İbrahim Hamdi'nin anlatılarının ortak noktalarından biridir. İbrahim Hamdi her ne kadar şehir hakkında fazla malumat vermemiş olsa da II. Bayezid'den bahsetmeden geçmemiştir. Ibrahim Hamdi, Bayezid'i anlattığı kısımda çok fazla detaya girmemiştir ancak o da Evliya Çelebi gibi şehrin esas kurucusunun II. Bayezid olduğunu vurgulamıştır.

Sarı Saltık'ın Balkanlar'da üstlendiği derviş rolünü oldukça önemseyen Evliya Çelebi şehrin kimlik kazanmasını sağlayan Bayezid'i de bir o kadar önemsemiştir. Bu nedenle o Nasıl ki Fatih Sultan Mehmet'i İstanbul'un fethini gerçekleştirerek Hristiyanların elinden alınmasını sağlayan bir "Fatih" olarak görüyorsa aynı şekilde Bayezid'i de Balkan fatihi olarak görmektedir. Ona göre Akşemseddin-Fatih ikilisinin temsil ettiği dini ve siyasi misyonunun benzerini Bayezid ve onun hocası Karaşemseddin'in taşıdığını düşünmektedir. Bu düşüncesinin bir diğer nedeni yine Sarı Saltık ve Bayezid arasında kurduğu ilişkidir. Sarı Saltık'ın Balkanlar'da üstlenmiş olduğu tebliğ vazifesinin siyasi ayağını Bayezid'in sürdürdüğünü düşünmektedir. Bu nedenle Evliya Çelebi Fatih ve Bayezid arasında bir ilişki kurmuş olmalıdır. Her iki padişah da Hıristiyan ülkelerinde sürdürdükleri fetihler ile bu bölgelerin müslümanlaşmasını sağlamışlardır. Her iki

40 "Saltukname'ye göre başlıcaları Kalliagra (Bulgaristan), Babadağı (Romanya), Blagay (Hersek), Ohri (Makedonya), Kruya (Akçehisar/Arnavutluk), Rumelifeneri (Istanbul), Babaeski (Edirne), Bor (Niğde), Diyarbakır, Tunceli ve Iznik gibi merkezlerde olmak üzere Saru Saltuk'un pek çok türbesi bulunmaktadır." Bkz. Vedat Turgut, Yitirilen Mirasımız: Balkanalrda Kurulan Osmanlı Vakıfları (Fethinden XVI. Yüzyılın Sonlarına Kadar), Eskişehir, 2016, s. 297-298.

41 Vedat Turgut, Yitirilen Mirasımız: Silistre Sancağı Vakıfları (Fethinden XVI. Yüzyılın Sonlarına Kadar), Eskişehir, 2016, s. 133.

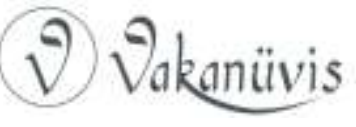


padişahın izlediği benzer siyaseti önemseyen Evliya Çelebi iki padişahında bu misyonunu ön plana çıkarmıştır.

Evliya Çelebi yukarıda bahsedildiği gibi şehri anlatırken yeri geldikçe II. Bayezid ve onun veliliğini hatırlamış ve okuyucusuna hatırlatmıştır. Bayezid'in veli bir padişah olduğunu sürekli vurgulamak isteyen Evliya Çelebi yine ona dair ilginç bir hikayeden bahseder. Bayezid'in nefsini öldürmek için yıllar boyunca bıçak ile kesilmiş hayvan yemediğini ancak canının et istediği bir gün içinden gelinciğe benzeyen bir hayvan çıktığını ve Bayezid'in nefsini temsil eden bu hayvana izin vererek et yemesine müsaade ettiğini anlatır. Fakat eti yiyen ve gelinciğe benzeyen bu yaratık tekrar Bayezid'in içine girmek istemiş ancak o buna müsaade etmeyerek nefsini Silahdar ağaya vurdurtmuştur. Evliya Çelebi onun bu şekilde nefsini öldürdüğünden ve bu nedenle onun veli bir padişah olduğunu yeri geldikçe vurgular ve Bayezid ile şehrin bir bütün olarak algılanmasını sağlar. Bu nedenle onu sık sık anma gereği duyar. Bu nedenle şehrin mistik ve manevi atmosferini vurgulamak adına yeri geldikçe Sarı Saltık ve Bayezid ile ilgili hikayelere metninde yer verir. Bu hikayeleri Babadağı şehrinde anlatmasının elbette ki şehrin ihya edicisi olarak önemsediği II. Bayezid ve şehrin müslümanlaşmasını sağlayan Sarı Saltık'ın Babadağı şehrinde bulunmuş olmaları ile alaklıdır.

Her iki müellifinde şehre dair bahsettiği ortak noktalardan bir diğeri de Kazak akınlarıdır. Yaklaşık beş yüz yıl boyunca Osmanlı hakimiyetinde kalan Babadağı şehrinin kuzeyinde Eflak, kuzeybatısında Boğdan bulunmaktaydı. Lehistan ve Kırım Hanlığının da bu bölgeye yakınlığı Kazak akınlarının sıklığını arttırmaktaydı. Evliya Çelebi Kazak akınlarından bahsederken yine Sarı Saltık'ı kullanmıştır. Yoğun şekilde bu bölgelere akınlar düzenleyen Kazaklar Tuna nehri yoluyla kayıklar ile Babadağı'na gelip Sarı Saltık'ın türbesini yağmalamışlardır. Yağma ettikleri türbeden kilim, tencere, tabak çanak, halı türü eşyaları alıp götürmüşlerdir. Ancak bu eşyaların hiç birini gemilerine ulaştırmayı başaramamış ve yollarda perişan olmuşlardır. Yaptıkları hatanın farkına varan Kazak askerleri yağmaladıkları eşyaları türbeye geri götürmek zorunda kalmışlardır. Ancak dönüşte düşmanın saldırısına uğramışlar ve hiç biri kurtulamadan ölmüşlerdir. Babadağı'na geldikleri gemi de dalgalar yüzünden parçalanmış ve içindeki malları etrafa saçılmış ve

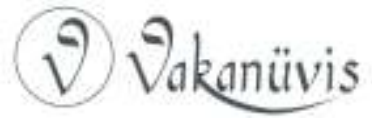


civarda yaşayan halk bu saçılan malları yağma etmiştir. ${ }^{42}$ Sarı Saltık gibi önemli bir erenin türbesini yağmalayan Kazaklar yaptıklarının bedelini önce yollarda telef olarak ardından ise gemilerinin karaya vurması ile ödemişlerdir. Burada dikkat çeken husus stratejik açıdan önemli ve bir o kadar da tehlikeli bir mevkide bulunan Babadağı'nın bir kaleye sahip olmayışıdır. Her ne kadar birçok padişah şehre kale yaptırma teşebbüsünde bulunmuş ve kale yapımına başlanmışsa da kale tamamıyla bitirilememiştir. IV. Murad Özi eyaletinde memur olan I. Ahmed'in damadı Koca Kenan Paşa'ya bir ferman göndererek "Başın sana gerek ise Babadağı şehri içinde cây-ı emân olmağiçün mahalle münâsib bir mürtefi' zemînde bir kal'a-i metîn bünyâd edüp der-i devletime miftâhların îsâl edesin" şeklinde uyararak Babadağı'na mutlaka bir kale yapılmasını tembihlemiştir. Ancak Kenan Paşa görevden alınmış ve kale yine tamamlanamamıştır. Evliya Çelebi'nin hamisi olan Melek Ahmed Paşa padişaha şehrin kalesinin inşaasını tamamlamak üzere başvurmuş bu nedenle Melek Ahmed Paşa'ya Rumeli Eyaleti bahşedilmiştir. Evliya'da onun hamiliğinde 1649/1650 yıllarında Babadağı'nda bulunma fırsatı yakalamış hatta yukarıda bahsettiğimiz gibi şehrin voyvodalığı ona verilmiştir. ${ }^{43}$ Ancak Melek Ahmed Paşa'da şehre bir kale yapılmasını sağlayamamıştır

İbrahim Hamdi de Kazak akınlarından bahsetmeden geçmemiştir. İbrahim Hamdi de Evliya'nın anlattığına benzer bir yağma hareketinden söz eder. Karadeniz' den Babadağı'na doğru oluşan bir girinti vasıtasıyla burada oluşan göl üzerinden Kazaklar şehir ile bağlantı kurmuş ve şehri talan etmişlerdir. ${ }^{44}$ Olaylar, Evliya Çelebi ve İbrahim Hamdi'nin eserlerinde zaman farklılığı dışında da bir nebze olsa da aynılık göstermektedir. Aradan geçen zamana rağmen Kazak akınları durmak

\footnotetext{
42 Evliya Çelebi Seyahatnamesi, Cilt III, s.204.

43 Evliya Çelebi şehrin paşa hassı olduğunu ve pek çok kalemin bu şehirden gelir sağladığını belirtmiştir: "Yüz aded tevâbi'iyle hükm-i hükûmât edüp paşaya beş kîse, hâkime dörd kîse ve zahîre bahâsı ağasına ve paşaya dörder kîse hâsıl olur, a'lâ hükûmetdir. Ve hâkim-i şer'-i Resûl-i mübîni üç yüz pâyesiyle şerîf kazâdır. Ammâ niçe kerre beş yüz akçe mollalara sadaka olunmuşdur." Şeklinde ifade ederek şehrin hem maddi olarak kazanç sağladığına hem de "şerif kazadır" ve "mollalara sadaka olunmuştur" ifadeleri ile manevi yönüne dikkat çekmek istemiştir. Bkz. Evliya Çelebi Seyahatnamesi, Cilt III, S.204.
}

${ }^{44}$ Atlas, vr. $178 \mathrm{~b}$.

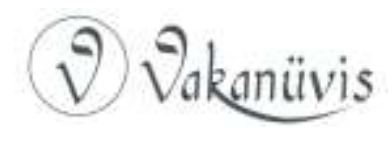


bilmemiş ve Babadağı halkı Kazaklar tarafından sürekli yağmalanmaya maruz kalmıştır.

Şehrin geçiş noktasında bulunması Babadă̆ı'na askeri üs niteliği kazandırmıştır. Bu nedenle siyasi olarak da önemli bir konumdadır. Nitekim Evliya bu duruma değinmiştir. Özü'de bulunduğu sırada Silistre, Babadağı ve Akkirman'ın üç tuğlu vezir eyaleti olduğu vurgusunu yapmıştır. ${ }^{45}$ Ancak bahsedilen şehirler akınlar nedeniyle hareketli halde olduğundan vezirinin sadece tek bir eyalet merkezinde değil bahsedilen üç şehirde yaklaşık on bin asker ile eyaletleri korunaklı hale getirerek kaldığını bildirir. Babadağı'nın bir serhad şehri olmasından olsa gerek Evliya'nın şehir ile ilgili bahsettiği bir diğer şey de Babadağı oklarıdır. Savaşın her daim yaşanılabilirliği, şehrin kritik bir noktada bulunması, Kazak akınlarına sık sık maruz kalıyor olmasından olsa gerek bir savaş gereci olarak şehirde çok çeşitli oklar olduğunu söylemiştir. ${ }^{46}$

\section{Sonuç}

Evliya Çelebi ve İbrahim Hamdi'nin anlattıkları dikkate alındığında ortak noktaları olmakla birlikte iki ayrı Babadağı resminin çizildiği aşikardır. Evliya Çelebi, bakımlı, zengin ve dindar bir Babadağı fotoğrafı çekerken; İbrahim Hamdi fakir, işlenmemiş, bakımsız ve dindarlıktan uzak, ahlaki açıdan yozlaşmış bir toplumu anlatır. Bunla birlikte onların anlattıklarının ortak noktaları da vardır. Her iki müellifte Sarı Saltık, II. Bayezid ve Kazak unsurlarına dikkat çekmiştir.

Evliya Çelebi, Sarı Saltık'ı ciddi anlamda detaylı bir şeklide anlatırken bunu Sarı Saltık ve Beyezid arasındaki menkıbeyle ortaklaşa özdeşleştirerek bir Babadağı anlatısı kurgulamıştır. Ibrahim Hamdi ise çok daha yalın ve sade bir şekilde bu mevzulara değinmiş Sarı Saltık'ın türbesinden kısaca bahsetmiş ve ardından II. Bayezid'in rolünü ifade etmiştir. Fakat Ibrahim Hamdi'nin burada Sarı Saltık ile ilgili görmüş

${ }^{45}$ Evliya Çelebi Seyahahatnamesi, Cilt V, s.94.

${ }^{46}$ Ve niçe yüz bin aded hadeng ü tîr ve sihem ü nâvek ve ok ve paşak u pojaklar kim her biri Mısır hadengi ve İslâmbol ve Gelibolu ve Bursa ve Babadağı okları kim peykânları Nahşevân ve Kırım paşakları idi. Bkz. Evliya Çelebi Seyahatnamesi, Cilt IV, s.156.

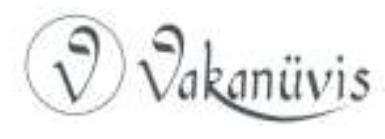


olduğu rüyayı anlatmış olması da ortak bir mistik boyut olarak altı çizilebilir.

Bir serhad şehri olan Babadağı seksen beş yıllık arayla şehri ziyaret etmiş iki ayrı kişi tarafından dile getirilmiş bu yönleri serhaddeki bir Osmanlı şehrinin merkez tarafından nasıl algılandığı nasıl farklı değerlendirildiği ya da zaman içerisinde nasıl dönüşüm geçirerek farklılaştığını ortaya koyma açısından önemlidir.

Evliya Çelebi ve Ibrahim Hamdi'nin ziyaretleri arasındaki seksen yıllık sürece bakıldığında her iki müellifin tanıttığı şehir birbirinden farklıdır. Babadağı şehri ve Evliya Çelebi'nin bu şehir ile özdeşleştirdiği Sarı Saltık ve onun türbesi gayet bakımlı ve güzeldir. Ancak İbrahim Hamdi'nin anlattığı Babadağı şehri ise yapıları ve insanları ile gayet soğuk görünmektedir. Bunun nedeni seksen yıllık süreçte Osmanlı Devleti'nin serhadde kaybettiği güç olmalıdır. Güç kaybeden devlet elini şehre uzatamamış ve bu nedenle Kazaklar ve Ruslar tarafından şehir tahrip edilmiş olmalıdır. Bu tahribatın sonucunda ise Evliya Çelebi'nin anlattıklarının aksine İbrahim Hamdi'nin anlattığı gibi bir şehir ortaya çıkmıştır. Osmanlı'nın güçlü dönemlerinde bakımlı bir şehir izlenimini uyandıran Babadağı devletin burada kaybettiği güç ile eski ihtişamını kaybetmiş olmalıdır.

Evliya Çelebi şehri seyyah kimliği ile İbrahim Hamdi ise coğrafyacı olarak değerlendirmiştir. Bu nedenle onun metni Evliya Çelebi'nin metnine göre biraz daha basit kalmaktadır. Ancak her iki müellifin verdiği bilgiler şehrin farklı zamanlarına ait ortak özelliklerini görebilmemiz açısından önem taşımaktadır. Farklı kimliklerine ve ziyaretleri arasındaki zaman farkına rağmen her ikisinin de anlattığı ortak noktalar vardır Bunlar; Sarı Saltık'ın dervişliği, şehre Kazakların sıkça yaptıkları akınlar ve II. Bayezid'dır. Ayrıca, Evliya Çelebi şehrin genel panoramasına dair bilgiler verirken İbrahim Hamdi ise daha çok insanına değinmiştir. Genel anlamda İnsan faktörü İbrahim Hamdi'nin eserinde daha yoğun görülürken Evliya Çelebi daha çok yapılara, gezilip görülecek yerlere dair bilgiler vermiş ve şehri Sarı Saltık etrafında kurgulayarak daha çok mistik yönüne değinmiştir. Aynı zamanda o II. Bayezid'in Babadağı'nda yaptığı imar faaliyetlerini ve yine onun vasıtasıyla şehrin yeni bir kimlik kazanmasını sağlamasından dolayı II.

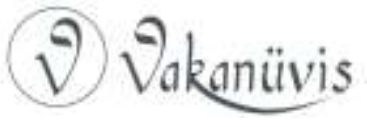


Bayezid'i oldukça önemsemiş ve metninde sıkça ona atıfta bulunmuştur.

Evliya Çelebi'nin anlattığı Babadağı şehri Sarı Saltık merkeze alınarak kurgulamıştır. Dolayısıyla şehrin jeopolitiği, tarihi ve yapıları Sarı Saltık merkezli anlatılmıştır. Sarı Saltık anlaşılmadan Evliya Çelebi'nin Babadağı ile ilgili kaleme almış olduğu şehir anlatısının anlaşılması kolay olmayacaktır. Bu nedenle hikayelerin pek çoğu bu minvalde değerlendirilmelidir. Kazak akınlarına sıkça maruz kalan bu şehir için Kazaklar'ın saldırılarından bahis açıldığında ya da şehirde bulunan yapılar, camiler anlatıldığında dahi Sarı Saltık'ı görmek mümkündür.

Biri şehri 17. Yüzyılda ziyaret eden seyyah-ı alem Evliya Çelebi, bir diğeri ise 18. Yüzyılda ziyaret etmiş hem asker hem seyyah hem de coğrafyacı olan İbrahim Hamdi'dir. Şehri pek çok kez ziyaret eden

Evliya Çelebi gerçekleştirdiği seyahatlerini genellikle devlet erkânının ile birlikte yapmıştır. Bu da onun ziyaretleri esnasında pek çok yere giriş çıkışını kolaylaştırmış, devlet erkânının ona sağladığı kolaylıklardan faydalanmasına olanak vermiştir. Bu nedenle onun anlatıları ibrahim Hamdi'ye göre daha olumlu görünmektedir.

Her iki seyyahın anlatıları, bulundukları sosyo-ekonomik durumlar nedeniyle veyahut devletin geçirmiş olduğu değişim ve dönüşüm sebebiyle aynı zamanda aradan geçen seksen beş yıllık süreç şehrin ve devletin geçirdiği değişim ve dönüşüme paralele olarak bir değişim sürecine girdiğini söyleyebiliriz. Devletin geçirdiği dönüşüme paralele olarak ona ait şehir ve kasabaların da değişmesini normal karşılayabiliriz. Bu nedenle şehir 16.yüzyılda daha bakımlı iken, İbrahim Hamdi döneminde bir önceki yüzyıla bakıldığında daha bakımsız bir şehir ile karşı karşıya kalmaktayız.

\section{Kaynakça}

Ak, Mahmut, "ibrahim Hamdi", Türkiye Diyanet Vakfı islam Ansiklopedisi (DiA), Cilt 21, Ankara 2000.

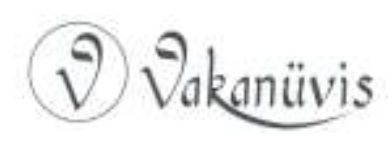


Aktepe, Münir "Babadağı”, Türkiye Diyanet Vakfı İslam Ansiklopedisi (DiA), Cilt IV, Ankara 1991.

Anetshofer, Helga, "Seyahatname'deki Sarı Saltık Menkıbeleri ve Bektaşi Sözlü Rivayeti" Ed. Nuran Tezcan), Doğumunun 400. Yılında Evliya Çelebi, T.C. Kültür ve Turizm Bakanlığı, Ankara 2011.

Bartınlı İbrahim Hamdi, Atlas, Süleymaniye Kütüphanesi Esad Efendi, 2044.

Bıyık, Ömer, Bartınlı Es- Seyyid Ibrahim Hamdi Efendi'nin Atlas'ında EflakBoğdan (Memleketeyn), Zafer Gölen, Balkan Tarihi, Cilt II, Osmanlı Mirasını ve Türk Kültürünü Araştırma Derneği Yayınları, 2016.

Erkal, Mehmet, "Cizye", Türkiye Diyanet Vakfı İslam Ansiklopedisi (DiA), Ankara, 1993.

Ertaş, M. Yaşar, Ibrahim Hamdi'ye Göre Silistre'den Vidin'e Tuna Kıyısındaki Osmanlı Şehirleri, Osmanlı ve Cumhuriyet Dönemi Türk-Bulgar ilişkileri Bildirileri, Eskişehir 2005, s.243-252

Evliya Çelebi Seyahatnamesi Topkapı Sarayı Kütüphanesi Bağdat 305 Numaralı Yazmanın Transkripsiyonu-Dizini,(Haz:Orhan Şaik Gökyay), 1. Kitap, Yapı Kredi Yayınları, İstanbul, 1996.

Evliya Çelebi Seyahatnamesi Topkapı Sarayı Kütüphanesi Bağdat 305 Numaralı Yazmanın Transkripsiyonu-Dizini,(Haz: Z. Kurşun Y. Dağlı, S.A. Kahraman), 2. Kitap, Yapı Kredi Yayınları, İstanbul, 1999.

Evliya Çelebi Seyahatnamesi Topkapı Sarayı Kütüphanesi Bağdat 305 Numaralı Yazmanın Transkripsiyonu-Dizini,(Haz: Y. Dağlı, S.A. Kahraman), 3. Kitap, Yapı Kredi Yayınları, İstanbul, 1999.

Evliya Çelebi Seyahatnamesi Topkapı Sarayı Kütüphanesi Bağdat 305 Numaralı Yazmanın Transkripsiyonu-Dizini,(Haz: Y. Dağlı, S.A. Kahraman), 4. Kitap, Yapı Kredi Yayınları, İstanbul, 2001.

Evliya Çelebi Seyahatnamesi Topkapı Sarayı Kütüphanesi Bağdat 305 Numaralı Yazmanın Transkripsiyonu-Dizini,(Haz: Y. Dağlı, S.A. Kahraman, İbrahim Sezgin), 5. Kitap, Yapı Kredi Yayınları, İstanbul, 2001.

Evliya Çelebi Seyahatnamesi Topkapı Sarayı Kütüphanesi Bağdat 305 Numaralı Yazmanın Transkripsiyonu-Dizini,(Haz: Y. Dağlı, S.A. Kahraman), 6. Kitap, Yapı Kredi Yayınları, İstanbul, 2002.

Evliya Çelebi Seyahatnamesi Topkapı Sarayı Kütüphanesi Bağdat 305 Numaralı Yazmanın Transkripsiyonu-Dizini,(Haz: Y. Dağlı, S.A. Kahraman R. Dankoff), 7. Kitap, Yapı Kredi Yayınları, İstanbul, 2003.

Evliya Çelebi Seyahatnamesi Topkapı Sarayı Kütüphanesi Bağdat 305 Numaralı Yazmanın Transkripsiyonu-Dizini,(Haz: Y. Dağlı, S.A. Kahraman R. Dankoff), 8. Kitap, Yapı Kredi Yayınları, İstanbul, 2003

Evliya Çelebi Seyahatnamesi Topkapı Sarayı Kütüphanesi Bağdat 305 Numaralı Yazmanın Transkripsiyonu-Dizini,(Haz: Y. Dağlı, S.A. Kahraman R. Dankoff), 9. Kitap, Yapı Kredi Yayınları, İstanbul, 2005

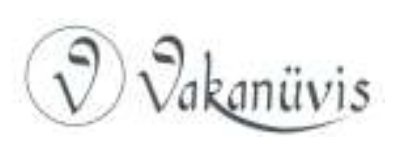


Evliya Çelebi Seyahatnamesi Topkapı Sarayı Kütüphanesi Bağdat 305 Numaralı Yazmanın Transkripsiyonu-Dizini,(Haz: Y. Dağlı, S.A. Kahraman R. Dankoff), 10. Kitap, Yapı Kredi Yayınları, İstanbul, 2007

Gökçe, Turan, "Babadağı Kasabasının XIX. Ortalarındaki Sosyal ve Ekonomik Yapısı", Tarih incelemeleri Dergisi, Cilt XXV, Sayı I, 2010.

Kiel, Michael, "Sarı Saltuk", Türkiye Diyanet Vakfı İslam Ansiklopedisi (DiA), Cilt 36, Ankara, 2009, s.147-148

Ocak, A. Yaşar, Osmanlı Sufiliğine Bakışlar-Makaleler, incelemeler, İstanbul 2010, Timaş Yayınları.

Orhonlu, Cengiz, "XVIII. Yüzyılda Osmanlılarda Coğrafya ve Bartınlı İbrahim Hamdi'nin Atlası, Tarih Dergisi, XIV/19.

Ökiç, M. Tayyib, "Sarı Saltık'a Ait Bir Fetva”, AÜiFD, Cilt I, Ankara 1952.

Öztürk, Yücel, Özü'den Tuna'ya Kazaklar-1, Yeditepe Yayınevi, İstanbul 2004

TADB. TTD. EV. 561, v. 308a 2004.

Turgut, Vedat, Yitirilen Mirasımız: Balkanlarda Kurulan Osmanlı Vakıfları (Fethinden XVI. Yüzyılın Sonlarına Kadar), Eskişehir 2016.

Turgut, Vedat, Yitirilen Mirasımız: Silistre Sancağı Vakıfları (Fethinden XVI. Yüzyılın Sonlarına Kadar), Eskişehir 2016.

Yılmaz, Hasan Hüseyin; Yıldırım, Ünal; Bartınlı İbrahim Hamdi'nin Atlas'ına Göre Bulgaristan'daki Bazı Yerleşmelerin Beşeri ve Ekonomik Özellikleri, Balkan Studies Geography and Geostrategy I, Ed. Deniz Ekinci, İstanbul 2011, s.548-561 